\title{
The Intracellular Loop between Domains I and II of the B-Type Calcium Channel Confers Aspects of G-Protein Sensitivity to the E-Type Calcium Channel
}

\author{
Karen M. Page, Gary J. Stephens, Nicholas S. Berrow, and Annette C. Dolphin \\ Department of Pharmacology, Royal Free Hospital School of Medicine, London NW3 2PF, United Kingdom
}

Neuronal voltage-dependent calcium channels undergo inhibitory modulation by G-protein activation, generally involving both kinetic slowing and steady-state inhibition. We have shown previously that the $\beta$-subunit of neuronal calcium channels plays an important role in this process, because when it is absent, greater receptor-mediated inhibition is observed (Campbell et al., 1995b). We therefore hypothesized that the calcium channel $\beta$-subunits normally may occlude G-proteinmediated inhibition. Calcium channel $\beta$-subunits bind to the cytoplasmic loop between transmembrane domains I and II of the $\alpha 1$-subunits (Pragnell et al., 1994). We have examined the hypothesis that this loop is involved in G-protein-mediated inhibition by making chimeras containing the I-II loop of $\alpha 1 \mathrm{~B}$ or $\alpha 1 \mathrm{~A}$ inserted into $\alpha 1 \mathrm{E}$ ( $\alpha 1 \mathrm{EBE}$ and $\alpha 1 \mathrm{EAE}$, respectively). This strategy was adopted because $\alpha 1 \mathrm{~B}$ (the molecular counterpart of N-type channels) and, to a lesser extent, $\alpha 1 \mathrm{~A}$ (P/Q-type) are G-protein-modulated, whereas this has not been observed to any great extent for $\alpha 1 \mathrm{E}$. Although $\alpha 1 \mathrm{~B}$, coexpressed with $\alpha 2-\delta$ and $\beta 1 \mathrm{~b}$ transiently expressed in COS-7 cells, showed both kinetic slowing and steady-state inhibition when recorded with GTP $\gamma \mathrm{S}$ in the patch pipette, both of which were reversed with a depolarizing prepulse, the chimera $\alpha 1 \mathrm{EBE}$ (and, to a smaller extent, $\alpha 1 \mathrm{EAE}$ ) showed only kinetic slowing in the presence of GTP $\gamma$ S, and this also was reversed by a depolarizing prepulse. These results indicate that the I-II loop may be the molecular substrate of kinetic slowing but that the steady-state inhibition shown by $\alpha 1 \mathrm{~B}$ may involve a separate site on this calcium channel.

Key words: calcium channel; G-protein; $\beta$-subunit; $\alpha 1 B$; $\alpha 1 E$; modulation
Voltage-dependent calcium channels are hetero-oligomers consisting of a number of subunits: $\alpha 1$, which is the pore-forming subunit, and several accessory subunits, including $\alpha 2-\delta$ and $\beta$ (Dolphin, 1995). Cloning has revealed six different $\alpha 1$-subunits, termed A, B, C, D, E, and S (Tanabe et al., 1987; Snutch et al., 1990). C, D, and S correspond to L-type channels (for review, see Dolphin, 1995), and $\alpha 1 \mathrm{~B}$ corresponds to the $\omega$-conotoxin (CTX) GVIA-sensitive N-type calcium channel (Dubel et al., 1992). In contrast, the physiological counterparts of the $\alpha 1 \mathrm{~A}$ and $\alpha 1 \mathrm{E}$ calcium channels are less clearly established (Sather et al., 1993; Soong et al., 1993; Schneider et al., 1994; Stea et al., 1994; Berrow et al., 1997; Stephens et al., 1997).

Neuronal and neurosecretory subtypes of calcium channels, including $\mathrm{N}, \mathrm{P}, \mathrm{Q}$, and $\mathrm{L}$, have been shown to be inhibited by various neurotransmitters and modulatory agents (Kleuss et al., 1991; Menon-Johansson et al., 1993; Mintz and Bean, 1993; Zhang et al., 1993). The modulation involves activation of a G-protein that is usually, but not invariably, pertussis toxinsensitive (Hille, 1992; Dolphin, 1995). In many systems evidence has been obtained that the G-protein involved is $\mathrm{G}_{\mathrm{o}}$ (Kleuss et al., 1991; Wang et al., 1992; Campbell et al., 1993). Recent expression

Received Oct. 25, 1996; revised Dec. 3, 1996; accepted Dec. 10, 1996.

We gratefully acknowledge financial support from the Wellcome Trust. We thank the following for generous gifts of cDNAs and reagents: Dr. T. Snutch (University of British Columbia, Vancouver, Canada), $\alpha 1 \mathrm{~A}, \alpha 1 \mathrm{E}$, and $\beta 1 \mathrm{~b}$; Dr. H. Chin (National Institutes of Health, Bethesda, Maryland), $\alpha 2-\delta$; Dr. J. Marshall (Yale University, New Haven, CT), GFP; Dr. Y. Mori (Seiriken, Okazaki, Japan), $\alpha 1$ B; Dr. S. Moss (University College London, London, UK), S65 $\rightarrow$ T GFP; Genetics Institute (Cambridge, MA), pMT2. We also thank Ms. A. Odunlami, Mr. I. Tedder, and Mr. D. Bel for technical assistance and Dr. A. Mathie for reading this manuscript. This work benefited from the use of the Seqnet facility (Daresbury, UK).

Correspondence should be addressed to Dr. A. C. Dolphin at the above address.

Copyright (C) 1997 Society for Neuroscience 0270-6474/97/171330-09\$05.00/0 studies have reconstituted G-protein modulation of cloned $\alpha 1 \mathrm{~A}$ and $\alpha 1 \mathrm{~B}$, but not $\alpha 1 \mathrm{E}$, calcium channels by several receptors (Bourinet et al., 1996; Toth et al., 1996). The main mechanism of modulation is thought to be membrane-delimited (i.e., not involving a soluble second messenger) and to be attributable to a direct interaction between activated G-protein subunits and one of the calcium channel subunits (Hille, 1992). The calcium channel $\beta$-subunits are intracellular proteins that bind to the cytoplasmic loop between domains I and II of the $\alpha 1$-subunit of all calcium channels (Pragnell et al., 1994). We have obtained evidence, by antisense depletion of calcium channel $\beta$-subunits from cultured rat dorsal root ganglion neurons, that coupling of calcium channels to G-proteins may involve direct or indirect competition between the activated G-protein and the calcium channel $\beta$-subunit for binding to the calcium channel $\alpha 1$-subunit (Berrow et al., 1995; Campbell et al., 1995b). This was confirmed in a coexpression study of calcium channel subunits in Xenopus oocytes, in which it was found that G-protein modulation of $\alpha 1 \mathrm{~A}$ by activation of expressed opiate receptors was greater in the absence of a coexpressed calcium channel $\beta$-subunit (Bourinet et al., 1996). Recent studies also suggest that G-protein subunits involved in interaction with $\alpha 1 \mathrm{~A}$ and $\alpha 1 \mathrm{~B}$ are the $\mathrm{G} \beta \gamma$-subunits (Herlitze et al., 1996; Ikeda, 1996). It is therefore possible that these G-protein subunits interact with the I-II loop of calcium channel $\alpha 1$-subunits to produce modulation of the channel.

The hypothesis that the I-II loop of $\alpha 1 \mathrm{~A}$ and $\alpha 1 \mathrm{~B}$ calcium channels is involved in G-protein modulation has been tested in the present study by creating a chimera, which consists of $\alpha 1 \mathrm{E}$ with the I-II loops from $\alpha 1 \mathrm{~A}$ or $\alpha 1 \mathrm{~B}$, to determine whether the ability to be modulated by G-protein activation in this way can be conferred on the $\alpha 1 \mathrm{E}$ calcium channel. 

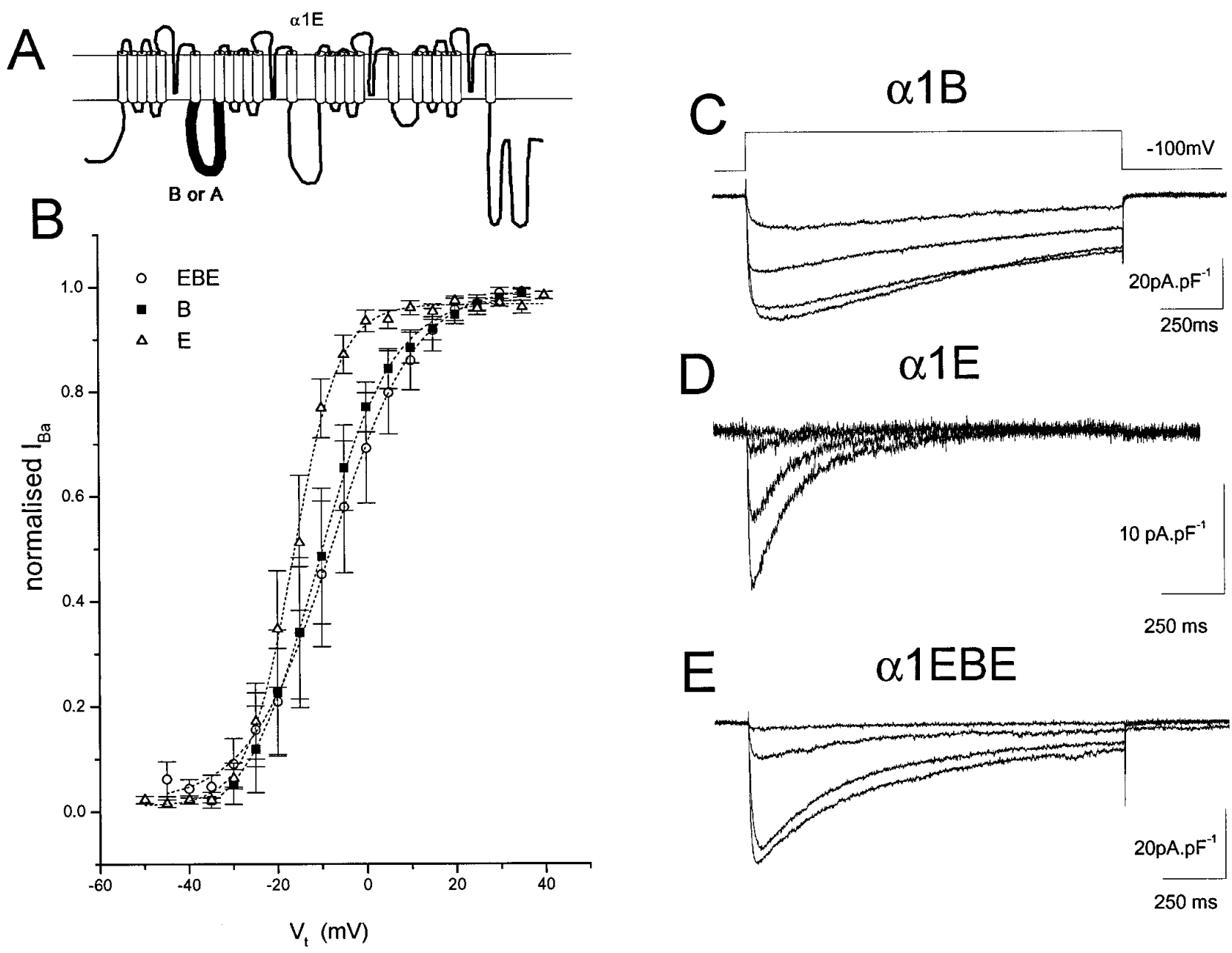

Figure 1. $\quad I_{\mathrm{Ba}}$ was recorded from cells transfected with $\alpha 1 \mathrm{E}, \alpha 1 \mathrm{~B}$, and $\alpha 1 \mathrm{EBE}$, together with $\alpha 2-\delta$ and $\beta 1 \mathrm{~b} . A$, Schematic diagram of the chimera $\alpha 1 \mathrm{EBE}$. $B$, The holding potential $V_{\mathrm{H}}$ was $-100 \mathrm{mV}$, and $20-30 \mathrm{msec}$ steps to increasing test potentials $V_{\mathrm{t}}$ were applied to maximally activate $I_{\mathrm{Ba}}$ without any inactivation. Tail current amplitudes were measured after repolarization to $-80 \mathrm{mV}$. The tail current $I-V$ relationships were normalized to the maximum tail current amplitude, and the mean \pm SEM of four, seven, and three experiments for $\alpha 1 \mathrm{~B}(\boldsymbol{\square}), \alpha 1 \mathrm{E}(\triangle)$, and $\alpha 1 \mathrm{EBE}(\mathrm{O})$ are given. The curves were fit (dotted lines) with a Boltzmann equation of the form: $I_{\text {norm }}=1 /\left\{1+\exp \left[\left(V_{\mathrm{t}}-V_{50}\right) / k\right]\right\}$, in which $V_{50}$ is the voltage for $50 \%$ activation and $k$ is the slope factor. The values for the parameters are given in Table 1 for the mean \pm SEM of the individual activation curves. $C-E$, Cells were held at $-100 \mathrm{mV}$, and $1500 \mathrm{msec}$ steps to voltages between -30 and $0 \mathrm{mV}(C, D)$ or -35 to $-5 \mathrm{mV}(E)(\Delta V 10 \mathrm{mV})$ were applied to examine the rate of inactivation of $I_{\mathrm{Ba}} \cdot \tau_{\text {inact }}$ values are given in Table 1.

\section{MATERIALS AND METHODS}

Construction of chimeras. The rat $\alpha 1 \mathrm{~A}$ (GenBank accession number M64373), $\alpha 1 \mathrm{E}$ (L15453), and $\beta 1 \mathrm{~b}$ (X61394) cDNAs (Starr et al., 1991; Soong et al., 1993; Tomlinson et al., 1993) were provided by Dr. T. Snutch (University of British Columbia, Vancouver, Canada) in a modified pMT2 expression vector (Genetics Institute, Cambridge, MA). The rabbit $\alpha 1 B$ (D14157) (Fujita et al., 1993) was provided by Dr. Y. Mori (Seiriken, Okazaki, Japan); the full-length rat $\alpha 2-\delta$ (neuronal splice variant, M86621) (Kim et al., 1992) was provided by Dr. H. Chin (National Institutes of Health, Bethesda, Maryland). The S65T mutant of GFP was a gift from Dr. S. Moss (University College London, London, UK). All DNAs were subcloned, using standard techniques, into the pMT2 vector for transient expression in COS-7 cells.

To produce chimeras containing the I-II loop of $\alpha 1 \mathrm{~A}$ or B substituted for the same region of $\alpha 1 \mathrm{E}$, we performed PCR on $\alpha 1 \mathrm{E}$ subcloned into the EcoRI site of the pcDNA3 vector (Invitrogen, San Diego, CA). Chimeric primers were directed against regions of the IS6 and IIS1 domains conserved between $\alpha 1 \mathrm{E}, \alpha 1 \mathrm{~A}$, and $\alpha 1 \mathrm{~B}$. Rat $\alpha 1 \mathrm{~A}$ and rabbit $\alpha 1 \mathrm{~B}$ I-II loops were amplified using the primers GGAACTGGCTGTACTTCATCC (at position 1024 in $\alpha 1 \mathrm{E}, 1010$ in $\alpha 1 \mathrm{~A}$, and 1112 in $\alpha 1 \mathrm{~B}$ ) and CACTCAGGACGATCCAGTAGAA (position 1500 in $\alpha 1 \mathrm{E}, 1492$ in $\alpha 1 \mathrm{~A}$, and 1594 in $\alpha 1 \mathrm{~B}$ ) to give 482 base pair (bp) fragments. Then the 482 bp products were used as primers in two individual second-stage PCR reactions in the presence of $\alpha 1 \mathrm{E}$, one containing the pcDNA3 forward primer, CTCACTATAGGGAGACCCAAGC, and the other containing the reverse primer, GACTTCATGGAGCTCATCAAGG (position 1852 in $\alpha 1 \mathrm{E}$ ). These PCR products (of 1430 and $834 \mathrm{bp}$ ) were combined in a third-stage reaction, in the absence of $\alpha 1 \mathrm{E}$, and extended to give a full-length product of $1782 \mathrm{bp}$. To facilitate subcloning, we put a $3314 \mathrm{bp}$ fragment (between $X b a \mathrm{I}$ nucleotide 822 and $A p a \mathrm{I} 4134$ ) into the $X b a \mathrm{I}-$ ApaI sites of pcDNA3. The $1782 \mathrm{bp}$ product was digested with the enzymes $X b a \mathrm{I}$ and $A c c \mathrm{~B} 7 \mathrm{I}$, and the 980 bp DNA was subcloned back into the $3314 \mathrm{bp}$ fragment in pcDNA3. All PCR was performed using the proofreading $P f u$ polymerase (Stratagene, La Jolla, CA) for 30 cycles of $95^{\circ} \mathrm{C}$ for $30 \mathrm{sec}, 54^{\circ} \mathrm{C}$ for $1 \mathrm{~min}$, and $75^{\circ} \mathrm{C}$ for $2 \mathrm{~min}$. The sequence of the chimeras between the $\mathrm{Xba \textrm {I }}(822 \mathrm{bp}, \alpha 1 \mathrm{E})$ and $A c c \mathrm{~B} 7 \mathrm{I}(1802 \mathrm{bp})$ sites was verified by the SequiTherm Cycle Sequencing kit (Epicenter Technologies, Madison, WI). The 3314 bp XbaI-ApaI DNA was subcloned back into the remainder of the $\alpha 1 \mathrm{E}$ pMT2 vector. This resulted in chimeras with substitution of the I-II loop of $\alpha 1 \mathrm{E}$ for that of $\alpha 1 \mathrm{~A}$ or B. Part of IS6 also was substituted, but this is identical in the three sequences, except for V293 in $\alpha 1 \mathrm{E}$, which is substituted by $\mathrm{M}$ in $\alpha 1 \mathrm{~A}, \mathrm{~B}$, and the chimeras.

Transfection of COS-7 cells. COS-7 cells were cultured and transfected by electroporation essentially as described previously (Campbell et al., 1995a). In all, 15, 10, 5, and $1 \mu \mathrm{g}$ of the pMT2- $\alpha 1, \alpha 2-\delta, \beta 1 \mathrm{~b}$, and GFP constructs, respectively, were used for transfection. If all subunits were 


\begin{tabular}{|c|c|c|c|c|}
\hline Control & $\alpha 1 \mathrm{~B}$ & $\alpha 1 \mathrm{E}$ & $\alpha 1 \mathrm{EBE}$ & $\alpha 1 \mathrm{EAE}$ \\
\hline Peak $I_{\mathrm{Ba}} \mathrm{pA} / \mathrm{pF}$ & $-30.9 \pm 7.2(8)$ & $-29.8 \pm 7.2(10)$ & $-25.6 \pm 7.6(8)$ & $-48.5 \pm 11.4(9)$ \\
\hline \multicolumn{5}{|l|}{ Current activation } \\
\hline$V_{50} \mathrm{mV}$ & $-11.4 \pm 3.9(4)$ & $-16.4 \pm 1.9(7)$ & $-9.1 \pm 7.1(3)$ & $-14.0 \pm 3.0(7)$ \\
\hline$k \mathrm{mV}$ & $6.0 \pm 0.7(4)$ & $4.3 \pm 0.8(7)$ & $6.6 \pm 0.7(3)$ & $6.6 \pm 0.7(n=7)$ \\
\hline \multicolumn{5}{|l|}{ Steady-state inactivation } \\
\hline$V_{50} \mathrm{mV}$ & $-61.3 \pm 7.1(3)$ & $-59.7 \pm 3.6(3)$ & $-56.8 \pm 4.1(4)$ & ND \\
\hline$k \mathrm{mV}$ & $-6.6 \pm 1.1(3)$ & $-11.5 \pm 1.3(3)$ & $-5.5 \pm 1.7(4)$ & ND \\
\hline$\tau_{\text {inact }}$ at $-10 \mathrm{mV} \mathrm{msec}$ & $1021 \pm 648(6)$ & $210 \pm 25(5)$ & $503.4 \pm 68.8^{\#}(7)$ & $438 \pm 65^{\#}(10)$ \\
\hline $\mathrm{GTP} \gamma \mathrm{S}$ & $\alpha 1 \mathrm{~B}(\mathrm{GTP} \gamma \mathrm{S})$ & $\alpha 1 \mathrm{E}(\mathrm{GTP} \gamma \mathrm{S})$ & $\alpha 1 \mathrm{EBE}(\mathrm{GTP} \gamma \mathrm{S})$ & $\alpha 1$ EAE $(\mathrm{GTP} \gamma \mathrm{S})$ \\
\hline Peak $I_{\mathrm{Ba}} \mathrm{pA} / \mathrm{pF}$ & $-18.7 \pm 6.1^{*}(6)$ & $-31.6 \pm 7.0(7)$ & $-20.3 \pm 4.3(12)$ & $-45.0 \pm 10.9(6)$ \\
\hline \multicolumn{5}{|l|}{ Current activation } \\
\hline$V_{50} \mathrm{mV}$ & $-7.9 \pm 5.3(4)$ & $-16.1 \pm 2.5(6)$ & $-10.7 \pm 4.7(3)$ & $-9.2 \pm 5.4(4)$ \\
\hline$k \mathrm{mV}$ & $7.6 \pm 1.1^{\star}(4)$ & $4.7 \pm 1.1(6)$ & $7.3 \pm 0.65^{\bullet}(3)$ & $6.2 \pm 0.5(4)$ \\
\hline \multicolumn{5}{|l|}{ Steady-state inactivation } \\
\hline$V_{50} \mathrm{mV}$ & $-58.5 \pm 4.5(3)$ & $-58.3 \pm 3.2(3)$ & $-54.7 \pm 3.5(3)$ & ND \\
\hline$k \mathrm{mV}$ & $-6.4 \pm 0.6(3)$ & $-9.9 \pm 1.3(3)$ & $-6.6 \pm 1.2(3)$ & ND \\
\hline$\tau_{\text {inact }}$ at $-10 \mathrm{mV} \mathrm{msec}$ & $1377 \pm 405^{\#}(7)$ & $218 \pm 24(5)$ & $470.8 \pm 91.7^{\bullet}(6)$ & $513 \pm 82^{\#}(5)$ \\
\hline
\end{tabular}

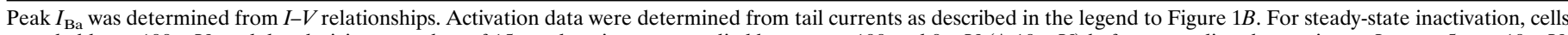

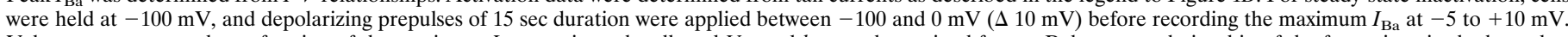

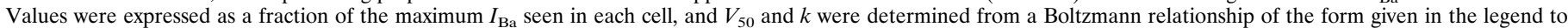

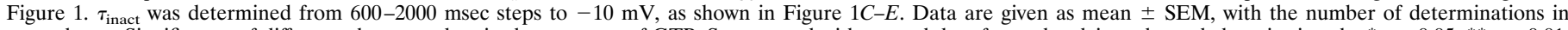

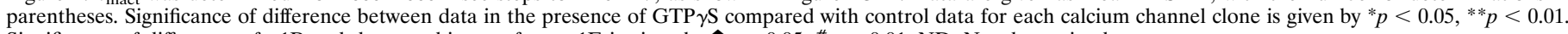
Significance of difference of $\alpha 1 \mathrm{~B}$ and the two chimeras from $\alpha 1 \mathrm{E}$ is given by $p<0.05$, ${ }^{\#} p<0.01$. ND, Not determined.

not transfected, the total $31 \mu \mathrm{g}$ of cDNA was made up by pMT2 vector. Successfully transfected cells were identified for electrophysiological studies by expression of GFP, and recordings were made between 2 and $4 \mathrm{~d}$ after transfection.

Electrophysiology. Recordings were made at room temperature (20$22^{\circ} \mathrm{C}$ ) from COS-7 cells that had been replated between 1 and $16 \mathrm{hr}$ previously, using a nonenzymatic cell dissociation medium (Sigma, St. Louis, MO). Only small cells with a circular morphology were used. Mean cell capacitance was $\sim 20 \mathrm{pF}$. Cells were viewed briefly with a fluorescein filter block, and only fluorescent cells expressing GFP, which were spatially isolated and with a compact morphology and smooth surface as visualized by Hoffmann optics, were used in experiments. The internal (pipette) and external solutions and recording techniques are similar to those previously described (Campbell et al., 1995b). The patch pipette solution contained (in mM): Cs aspartate 140, EGTA 5, $\mathrm{MgCl}_{2} 2, \mathrm{CaCl}_{2}$ $0.1, \mathrm{~K}_{2}$ ATP 2, GTP 0.1, and HEPES 10, pH 7.2, 310 mOsm with sucrose. GTP $\gamma \mathrm{S}(100 \mu \mathrm{M})$ was included where stated. The external solution contained (in $\mathrm{mM}$ ): tetraethylammonium (TEA) bromide $160, \mathrm{KCl} \mathrm{3}$, $\mathrm{NaHCO}_{3} 1.0, \mathrm{MgCl}_{2}$ 1.0, HEPES 10, glucose 4, and $\mathrm{BaCl}_{2} 10, \mathrm{pH} 7.4,320$ mOsm with sucrose. Pipettes of resistance $2-4 \mathrm{M} \Omega$ were used, and the holding current at $-100 \mathrm{mV}$ was normally $<20 \mathrm{pA}$. Cells were used only where series resistance was compensated to $80 \%$, and space clamp was adequate as judged by graded activation of $I_{\mathrm{Ba}}$. The voltage errors from the residual uncompensated series resistance were $<1 \mathrm{mV}$ for the largest currents, and no further correction was made. An Axopatch 1D or Axon $200 \mathrm{~A}$ amplifier was used, and data were filtered at $2-5 \mathrm{kHz}$ and digitized at $5-20 \mathrm{kHz}$. Analysis was performed by pClamp 6 and Origin 3.5. Data are given as mean $\pm \mathrm{SEM}$, and current records are shown after leak and residual capacitance current subtraction $(\mathrm{P} / 4$ or $\mathrm{P} / 8$ protocol).

\section{RESULTS}

\section{Characteristics of $\alpha 1 \mathrm{E}$ and $\alpha 1 \mathrm{~B}$ expressed in COS-7 cells}

The $\alpha 1$-subunits $\mathrm{A}, \mathrm{B}$, and $\mathrm{E}$ and the $\alpha 1 \mathrm{EBE}$ chimera (Fig. $1 A$ ) were transiently expressed with accessory subunits $\alpha 2-\delta$ and $\beta 1 \mathrm{~b}$ in COS-7 cells. The properties of $\alpha 1 \mathrm{E}$ and $\alpha 1 \mathrm{~B}$ were clearly distinct from each other in terms of both voltage dependence of their activation (Fig. 1B) and kinetics of inactivation (Fig. 1C,D). $\alpha 1 \mathrm{E}$ was activated at slightly more negative potentials than $\alpha 1 \mathrm{~B}$, the midpoint for activation being $5 \mathrm{mV}$ more hyperpolarized, and it showed a slightly steeper voltage dependence (Fig. $1 B$, Table 1). Most strikingly, it also showed a much greater degree of inactivation than $\alpha 1 \mathrm{~B}$ during $1500 \mathrm{msec}$ steps (Fig. $1 D$ compared with Fig. 1C). However, the steady-state inactivation profiles of $\alpha 1 \mathrm{E}$ and $\alpha 1 \mathrm{~B}$ were very similar (Table 1 ). The chimera $\alpha 1 \mathrm{EBE}$, the sequence of which was identical to that of $\alpha 1 \mathrm{E}$ except for replacement of the entire intracellular loop between domains I and II with that of $\alpha 1 \mathrm{~B}$ and one substitution in IS6 (Fig. $1 A$; see Materials and Methods), showed a more depolarized voltage dependence of activation than $\alpha 1 \mathrm{E}$, similar to $\alpha 1 \mathrm{~B}$ (Fig. $1 B$ ). Its steadystate inactivation parameters were similar to $\alpha 1 \mathrm{E}$ and $\alpha 1 \mathrm{~B}$ (Table $1)$; it showed inactivation kinetics intermediate between those of $\alpha 1 \mathrm{~B}$ and $\alpha 1 \mathrm{E}$ (Fig. $1 E$, Table 1 ). The current densities resulting from expression of $\alpha 1 \mathrm{E}, \alpha 1 \mathrm{~B}$, and $\alpha 1 \mathrm{EBE}$ were similar (Table 1 ), but the percentage of GFP-positive cells expressing $\alpha 1 \mathrm{E}$ was greater $(\sim 80 \%)$ than for $\alpha 1 \mathrm{~B}(\sim 40 \%)$. The percentage of cells expressing $\alpha 1 \mathrm{EBE}$ was similar to that for $\alpha 1 \mathrm{E}$.

\section{Comparison of the effect of GTP $\gamma \mathrm{S}$ on the kinetics of activation of $\alpha 1 B, \alpha 1 E$, and $\alpha 1 E B E$}

To examine the effect of G-protein activation on the expressed calcium channel currents, we included $100 \mu \mathrm{M}$ GTP $\gamma \mathrm{S}$ in the patch pipette, and currents were recorded after it had diffused into the cell for 2-5 min. GTP $\gamma \mathrm{S}$ produced a clear slowing of the activation of $\alpha 1 \mathrm{~B}$, but not $\alpha 1 \mathrm{E}$, currents as compared with control currents recorded in the absence of GTP $\gamma \mathrm{S}$ (Fig. $2 A$ compared with $2 B$ ), indicative of G-protein modulation of $\alpha 1 \mathrm{~B}$, but not $\alpha 1 \mathrm{E}$, currents. This was most evident from examination of the time constant of activation $\left(\tau_{\text {act }}\right)$ at depolarizations between -20 and $0 \mathrm{mV}$ when the current amplitude is submaximal (Fig. 2D).

Because of the possibility that the site of G-protein modu- 


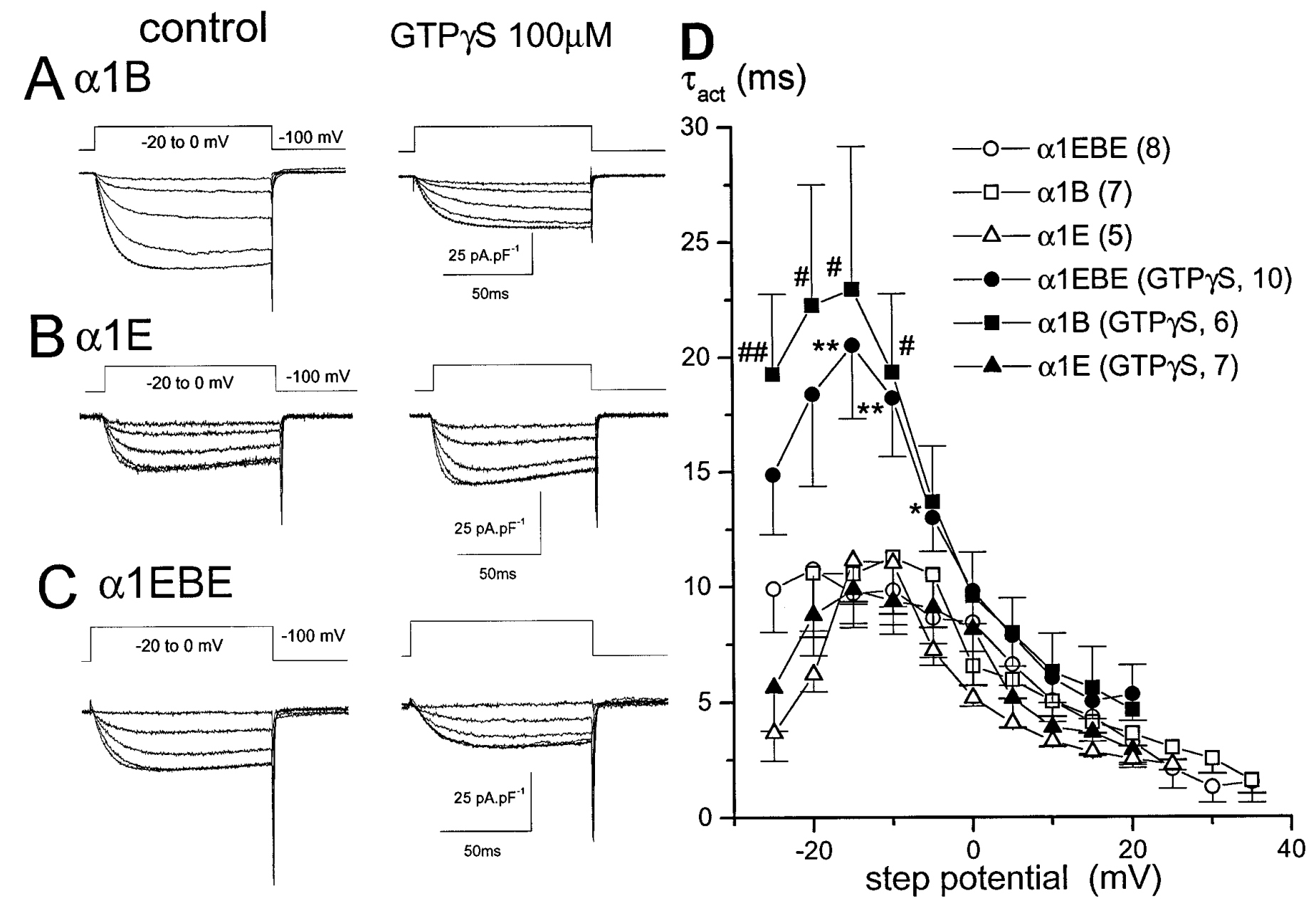

Figure 2. $\quad I_{\mathrm{Ba}}$ was recorded from cells transfected with $\alpha 1 \mathrm{~B}(A), \alpha 1 \mathrm{E}(B)$, and $\alpha 1 \mathrm{EBE}(C)$, together with $\alpha 2-\delta$ and $\beta 1 \mathrm{~b}$. Cells were held at $-100 \mathrm{mV}$, and $100 \mathrm{msec}$ steps from $-20 \mathrm{mV}(\Delta 5 \mathrm{mV})$ were applied to examine the kinetics of activation of $I_{\mathrm{Ba}}$. The examples given are from different cells recorded either in the absence or in the presence of GTP $\gamma \mathrm{S}$ in the patch pipette. Mean amplitudes of the maximum $I_{\mathrm{Ba}}$ are given in Table 1. A single exponential was fit to the activation phase of the current, initiated after the transient positive-going current had decayed back to baseline, to quantify the rate of activation. Examples of single exponential fits (heavy dotted lines) are given for the maximum currents at $0 \mathrm{mV}$ for the two families of traces in $A$. The time constant of activation $\left(\tau_{\text {act }}\right)$ is $7.9 \mathrm{msec}$ for control and $11.0 \mathrm{msec}$ for the GTP $\gamma \mathrm{S}$-containing cell. $D$, The $\tau_{\text {act }}$ values were plotted against voltage for $\alpha 1 \mathrm{EBE}(\bigcirc), \alpha 1 \mathrm{~B}(\square)$, and $\alpha 1 \mathrm{E}(\triangle)$ ), both under control conditions (open symbols) and in the presence of GTP $\gamma \mathrm{S}($ closed symbols). The mean $\pm \mathrm{SEM}$ is shown for the number of cells given in parentheses on the figure. It is clear that only $\alpha 1 \mathrm{~B}$ and $\alpha 1 \mathrm{EBE}$ show slowed activation in the presence of GTP $\gamma \mathrm{S}$, particularly at submaximal voltages for $I_{\mathrm{Ba}}$ activation. Statistical significance (Student's $t$ test) of GTP $\gamma \mathrm{S}$ groups from their respective controls is given by ${ }^{*} p<0.05,{ }^{* *} p<0.01$ for $\alpha 1 \mathrm{EBE}, \# p<0.05$ and \#\#p $<0.01$ for $\alpha 1 \mathrm{~B}$.

lation of calcium channels resided on the I-II loop of the $\alpha 1 \mathrm{~B}$-subunit, we examined the ability of the $\alpha 1 \mathrm{EBE}$ chimera to be modulated by G-protein activation. GTP $\gamma \mathrm{S}$ now produced a slowing of the activation of the $\alpha 1 \mathrm{EBE}$ calcium channel current similar to that found for $\alpha 1 \mathrm{~B}$ (Fig. 2C,D). Thus the incorporation of the I-II loop from $\alpha 1 \mathrm{~B}$ into $\alpha 1 \mathrm{E}$ endows the chimera with the ability to be modulated by G-proteins. However, a comparison of the current-voltage relationships from cells recorded in the absence or presence of GTP $\gamma \mathrm{S}$ in the patch pipette indicates that $G$-protein activation has had a greater inhibitory effect on the amplitude of $\alpha 1 \mathrm{~B}$ currents (Fig. 3A) than is evident for the $\alpha 1 \mathrm{EBE}$ chimera (Fig. $3 B$ ). No effect was observed of GTP $\gamma \mathrm{S}$ on the current-voltage relationships for $\alpha 1 \mathrm{E}$ (Fig. $3 C$ ), and there was no effect of G-protein activation on the steady-state inactivation parameters for any of the calcium channel clones (Table 1).

\section{Effect of depolarizing prepulses on activation of parental $\alpha 1 \mathrm{E}, \alpha 1 \mathrm{~B}$, and chimeric $\alpha 1 \mathrm{EBE}$ calcium channels}

Depolarizing prepulses previously have been shown to reverse the G-protein modulation of calcium currents (Tsunoo et al., 1986; Grassi and Lux, 1989). This protocol was used in the present study to examine the extent of calcium channel current modulation by GTP $\gamma$ S for both parental and chimeric channels. Depolarizing prepulses to varying voltages $(+80$ to $+140 \mathrm{mV})$ markedly enhanced calcium current activation and amplitude of $\alpha 1 \mathrm{~B}$ currents in the presence of GTP $\gamma \mathrm{S}$ while having less effect on $\alpha 1 \mathrm{~B}$ currents in the absence of GTP $\gamma \mathrm{S}$. The maximum enhancement was observed with $100 \mathrm{msec}$ depolarizing prepulses to $+120 \mathrm{mV}$ (results not shown). For subsequent experiments, a constant prepulse to $+120 \mathrm{mV}$ was used, and test pulses of increasing amplitude were applied immediately before $\left(\mathrm{P}_{1}\right)$ and $10 \mathrm{msec}$ after $\left(\mathrm{P}_{2}\right)$ the 


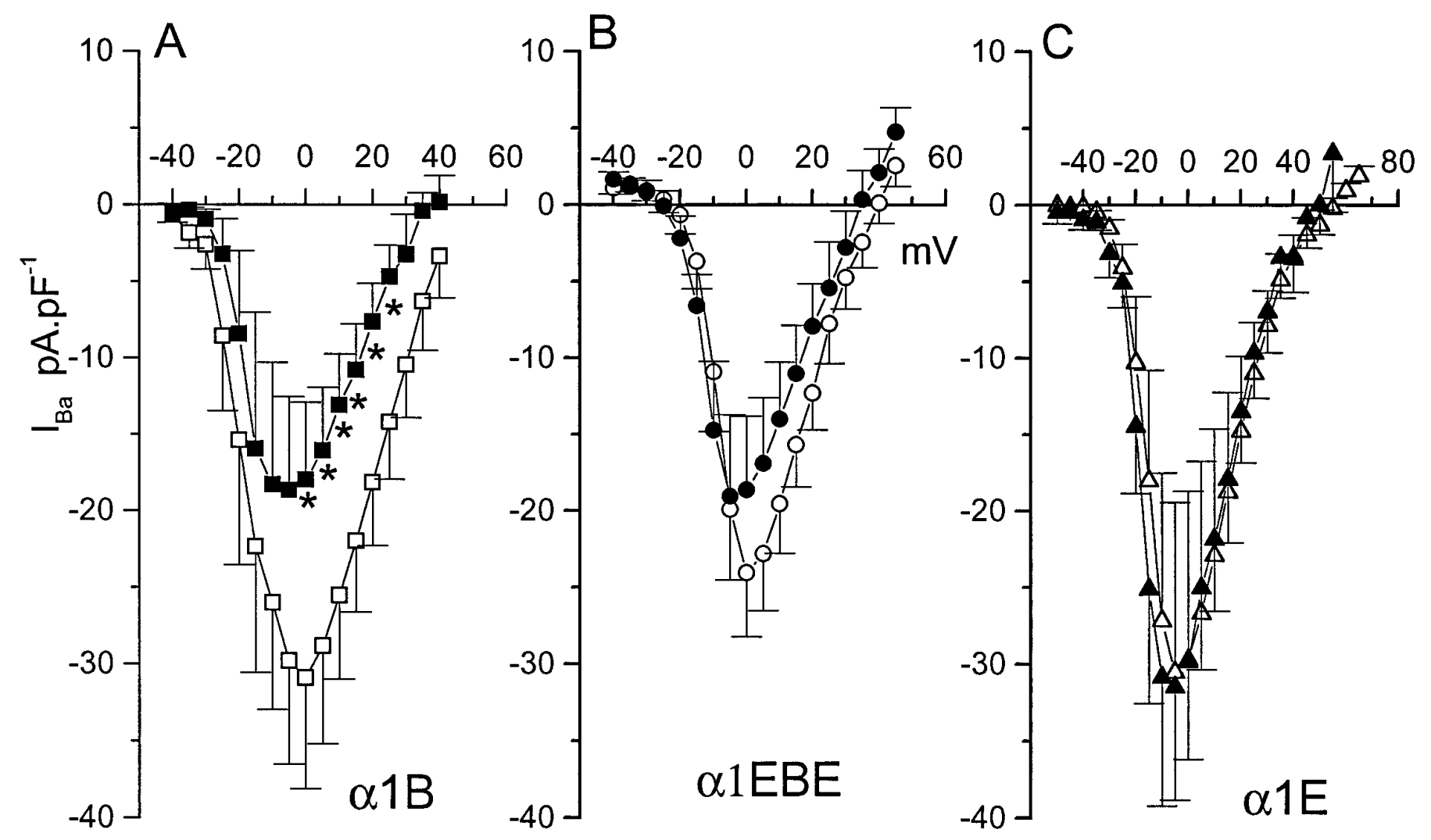

Figure 3. Mean current-voltage relationships were determined for cells under control conditions (open symbols) and in the presence of GTP $\gamma \mathrm{S}$ (closed symbols $)$ for $\alpha 1 B(\square, 8 ; \mathbf{\square}, 6), \alpha 1 E B E(\bigcirc, 12 ; \bullet, 9)$, and $\alpha 1 E(\triangle, 6 ; \boldsymbol{\Delta}, 6)$. The data are the mean \pm SEM for the numbers given in parentheses. Statistical significance between control and GTP $\gamma \mathrm{S}$ groups is given by ${ }^{*} p<0.05$ (Student's $t$ test).

depolarizing prepulse. Thus the effect of the depolarizing prepulse on current-voltage and $\tau_{\text {act }}$-voltage relationships was examined. For $\alpha 1 \mathrm{~B}$, in GTP $\gamma \mathrm{S}$-dialyzed cells, the prepulse produced a marked enhancement of the calcium channel current amplitude and its rate of activation, particularly at small depolarizations (Fig. $4 A-C$ ). Therefore, the prepulse shifted the voltage for half-activation of the current by approximately $-6 \mathrm{mV}$. At -20 $\mathrm{mV}$, the $\mathrm{P}_{2} / \mathrm{P}_{1}$ ratio was $0.61 \pm 0.04(n=6)$ for $\tau_{\text {act }}$ and $1.76 \pm$ $0.23(n=6)$ for $I_{\mathrm{Ba}}$ amplitude. No significant effect was observed either on $\tau_{\text {act }}$ or $I_{\mathrm{Ba}}$ amplitude in the absence of GTP $\gamma \mathrm{S}$ (Fig. 4D-F).

For $\alpha 1 \mathrm{E}$, there was little effect at any potential of a depolarizing prepulse, either on $\tau_{\text {act }}$ or on current amplitude in the presence or absence of GTP $\gamma \mathrm{S}$. For example, at $-20 \mathrm{mV}$ in control cells, $\tau_{\text {act }}$ was $5.7 \pm 0.6 \mathrm{msec}$ and $4.5 \pm 0.4 \mathrm{msec}$ before and after the prepulse, respectively. The $\mathrm{P}_{2} / \mathrm{P}_{1}$ ratio was $0.81 \pm 0.05(n=6 ; p<$ 0.05 , paired $t$ test). The corresponding values were $5.4 \pm 1.7 \mathrm{msec}$ and $4.6 \pm 1.2 \mathrm{msec}$ in the presence of GTP $\gamma \mathrm{S}$, giving a $\mathrm{P}_{2} / \mathrm{P}_{1}$ ratio of $0.89 \pm 0.04(n=5)$. At the same potential, the $\mathrm{P}_{2} / \mathrm{P}_{1}$ ratios for the current amplitudes were $0.99 \pm 0.06$ in control cells and $1.03 \pm 0.04$ in GTP $\gamma \mathrm{S}$-dialyzed cells. Thus we conclude that $\alpha 1 \mathrm{E}$ is not subject to G-protein modulation in this system, although there is a small degree of prepulse facilitation of the control activation kinetics.

In marked contrast with its effect on the parental $\alpha 1 \mathrm{E}$, the depolarizing prepulse significantly enhanced the rate of activation of the chimera $\alpha 1 \mathrm{EBE}$ calcium channel current (Fig. 5), particularly in the presence of GTP $\gamma \mathrm{S}$ (Fig. $5 A, C$ ). For example, at -20
$\mathrm{mV}, \mathrm{P}_{2} / \mathrm{P}_{1}$ for $\tau_{\text {act }}$ was $0.63 \pm 0.05(n=8$; Fig. $5 C)$ in the presence of GTP $\gamma \mathrm{S}$ and $0.75 \pm 0.08(n=5$; Fig. $5 F)$ under control conditions. Clearly, there is some prepulse facilitation of the activation kinetics of $\alpha 1 \mathrm{EBE} I_{\mathrm{Ba}}$ in the absence of GTP $\gamma \mathrm{S}$, but this is increased greatly in its presence. However, there was no effect of the prepulse on current amplitude, either in the presence or absence of GTP $\gamma \mathrm{S}$ (Fig. $5 B, E$ ).

\section{Characteristics of chimeric $\alpha 1 E A E$ expressed in COS-7 cells}

Because there is evidence in the literature that $\alpha 1 \mathrm{~A}$ also may be G-protein-modulated, although to a more limited extent than $\alpha 1 \mathrm{~B}$ (Bourinet et al., 1996), a similar chimera also was made containing the intracellular I-II loop of $\alpha 1 \mathrm{~A}$, replacing the I-II loop of $\alpha 1 \mathrm{E}$ ( $\alpha 1 \mathrm{EAE})$. We previously have described the properties of the $\alpha 1 \mathrm{~A}$ clone expressed in the COS-7 cell expression system (Berrow et al., 1997). It was not examined further in this study, because its low expression levels precluded direct comparison. The properties of the $\alpha 1 \mathrm{EAE}$ chimera are shown in Figure 6 and Table 1 . The voltage dependence of activation was similar to $\alpha 1 \mathrm{E}$ (Table 1 ) and much more negative than $\alpha 1 \mathrm{~A}\left(V_{50}+9.5 \mathrm{mV}\right.$; Berrow et al., 1997). The inactivation kinetics were intermediate between $\alpha 1 \mathrm{E}$ and $\alpha 1 \mathrm{~B}$, being similar to $\alpha 1 \mathrm{EBE}$ (Fig. $6 A$, Table 1 ). A comparison of $\tau_{\text {inact }}$ between $\alpha 1 \mathrm{EAE}$ and data previously obtained for $\alpha 1 \mathrm{~A}$ was difficult because of the differences in their voltage range for activation, given the voltage dependence of inactivation kinetics. However, at $+10 \mathrm{mV}, \tau_{\text {inact }}$ was $297 \pm 54 \mathrm{msec}(n=8)$ for 


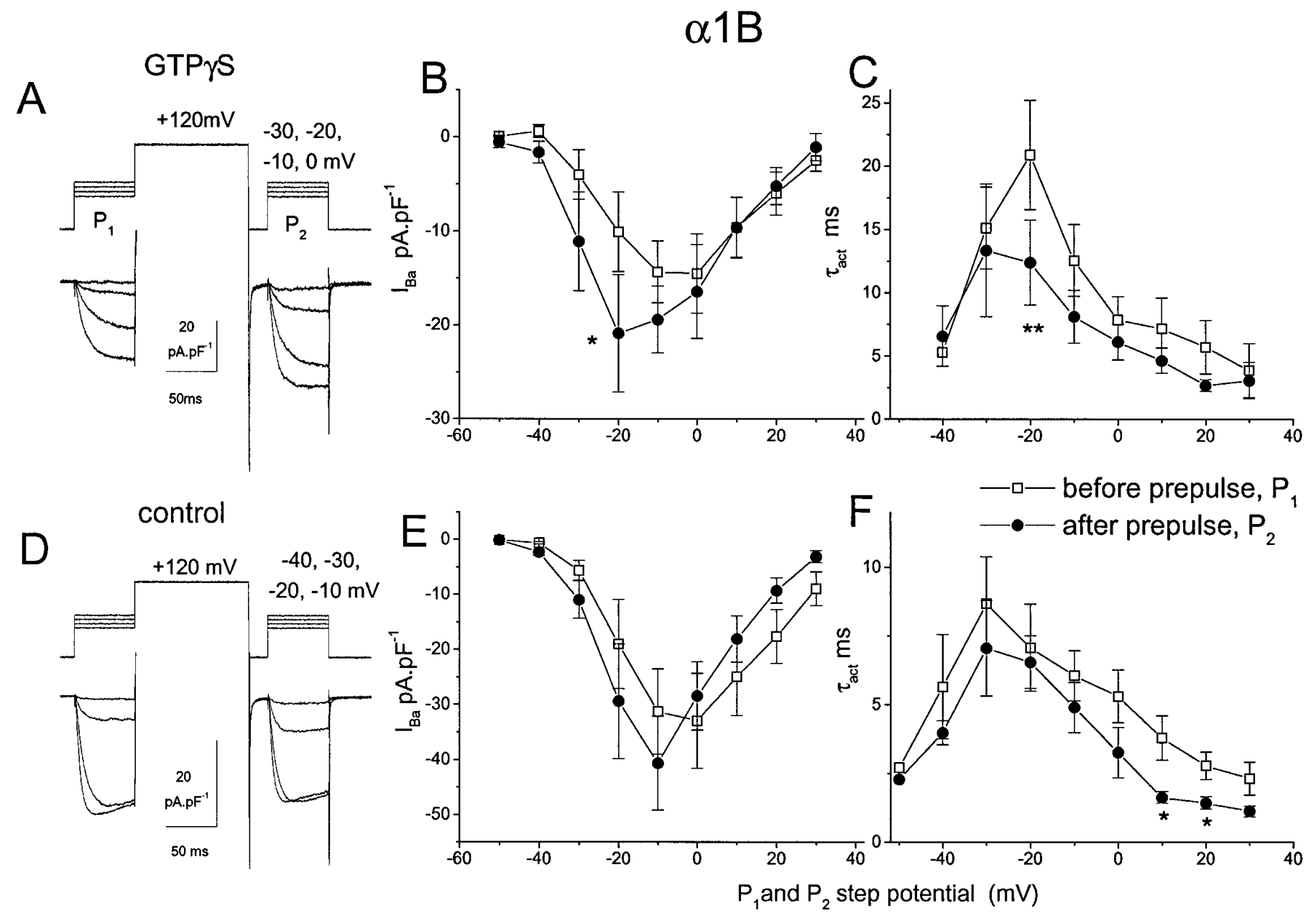

Figure 4. Cells were transfected with $\alpha 1 \mathrm{~B}, \alpha 2-\delta$, and $\beta 1 \mathrm{~b}$ and recorded after $3-4 \mathrm{~d}$ in culture. $I_{\mathrm{Ba}}$ was examined immediately before $\left(P_{1}\right)$ and $10 \mathrm{msec}$ after $\left(P_{2}\right)$ application of a depolarizing prepulse to $+120 \mathrm{mV}$, according to the voltage protocol given in $A$ and $D . P_{1}$ and $P_{2}$ both were augmented at 0.05 $\mathrm{Hz}$ from $-40 \mathrm{mV}$ with $\Delta 10 \mathrm{mV}$ to activate currents in cells recorded in the presence of GTP $\gamma \mathrm{S}(A)$ or in control cells $(B)$. The $I_{\mathrm{Ba}}$ amplitude and $\tau_{\text {act }}$ were determined for the currents evoked by $P_{1}(\square)$ and $P_{2}(\bullet)$, and these are plotted against the step potential of $P_{1}$ and $P_{2}$ for $I_{\mathrm{Ba}}$ and $\tau_{\text {act }}$ in GTP $\gamma$ S-modulated $(B, C)$ and control $(E, F)$ cells, respectively. The mean \pm SEM is given for six GTP $\gamma$ S-modulated and seven control cells. The statistical significance of difference between both $\tau_{\text {act }}$ and $I_{\mathrm{Ba}}$ amplitude evoked in $P_{1}$ and $P_{2}$ was determined by paired $t$ test; ${ }^{*} p<0.05$, ${ }^{* *} p<0.01$.

$\alpha 1 \mathrm{EAE}$, as compared with $414 \pm 15 \mathrm{msec}(n=5)$ at $+15 \mathrm{mV}$ for $\alpha 1 \mathrm{~A}$ (Berrow et al., 1997).

A small effect of GTP $\gamma \mathrm{S}$ was observed on the kinetics of activation of $\alpha 1 \mathrm{EAE}$ (Fig. $6 B$, Table 1 ), $\tau_{\text {act }}$ for $I_{\mathrm{Ba}}$ at $-20 \mathrm{mV}$ being $9.7 \pm 1.6$ msec $(n=7)$ in control cells and $14.4 \pm 2.1 \mathrm{msec}(n=5)$ in cells recorded in the presence of GTP $\gamma \mathrm{S}$. In agreement with this, in GTP $\gamma$ S-dialyzed cells a depolarizing prepulse to $+120 \mathrm{mV}$ applied before a test pulse to $-20 \mathrm{mV}$ decreased $\tau_{\text {act }}$ from $9.1 \pm 2.0 \mathrm{msec}$ to $7.1 \pm 2.1 \mathrm{msec}(n=5 ; p<0.01$, paired $t$ test; Fig. $6 C)$. However, the same depolarizing prepulse produced no facilitation of the amplitude of $I_{\mathrm{Ba}}(50.9 \pm 20.7 \mathrm{pA} / \mathrm{pF}$ to $55.6 \pm 20.6 \mathrm{pA} / \mathrm{pF} ; n=5 ;$ Fig. $6 C)$. In control cells, no effect of the same depolarizing prepulse was observed either on the amplitude or $\tau_{\mathrm{act}}$ of $I_{\mathrm{Ba}}$.

\section{DISCUSSION}

\section{G-protein regulation of $\alpha 1 B$ and $\alpha 1 E B E$ in COS-7 cells}

The most significant result of the present study is that the cytoplasmic loop between domains I and II of the B-type calcium channel $\alpha 1$-subunit is sufficient to confer aspects of G-protein sensitivity on the $\alpha 1 \mathrm{E}$ calcium channel clone, which itself shows no or little G-protein modulation (Bourinet et al.,
1996; Toth et al., 1996; Yassin et al., 1996). It was first necessary for us to demonstrate classical G-protein modulation of the $\alpha 1 \mathrm{~B}$ calcium channel expressed in COS-7 cells. Because of the lack of suitable endogenous receptors in COS-7 cells, we have chosen to produce G-protein activation by dialysis of GTP $\gamma \mathrm{S}$ from the patch pipette. The expressed $\alpha 1 \mathrm{~B}$ currents exhibited both of the classical characteristics of G-protein modulation: reduced amplitude and slowed activation in the presence of GTP $\gamma \mathrm{S}$. Furthermore, both of these effects could be reversed by a depolarizing prepulse. This has been shown previously for opiate modulation of $\alpha 1 \mathrm{~B}$ in oocytes (Bourinet et al., 1996) and for somatostatin modulation of $\alpha 1 \mathrm{~B}$ in a stable HEK293 cell line (Toth et al., 1996). Although COS-7 cells contain no $\mathrm{G} \alpha_{\mathrm{o}}$, they have several $\mathrm{G} \alpha_{\mathrm{i}}$ species as well as $\mathrm{G} \alpha_{\mathrm{q}}$ and $\mathrm{G} \alpha_{11}$ (Boyer et al., 1989). GTP $\gamma \mathrm{S}$ is able to bypass the specificity for $G_{o}$ of receptor-mediated modulation of calcium channels (McFadzean et al., 1989; Kleuss et al., 1991; Campbell et al., 1993) and will liberate $\mathrm{G} \beta \gamma$ from all available sources. Recent evidence suggests that this is the G-protein species responsible for modulation of the neuronal calcium channels $\alpha 1 \mathrm{~A}$ and $\alpha 1 \mathrm{~B}$ (Herlitze et al., 1996; Ikeda, 1996). 


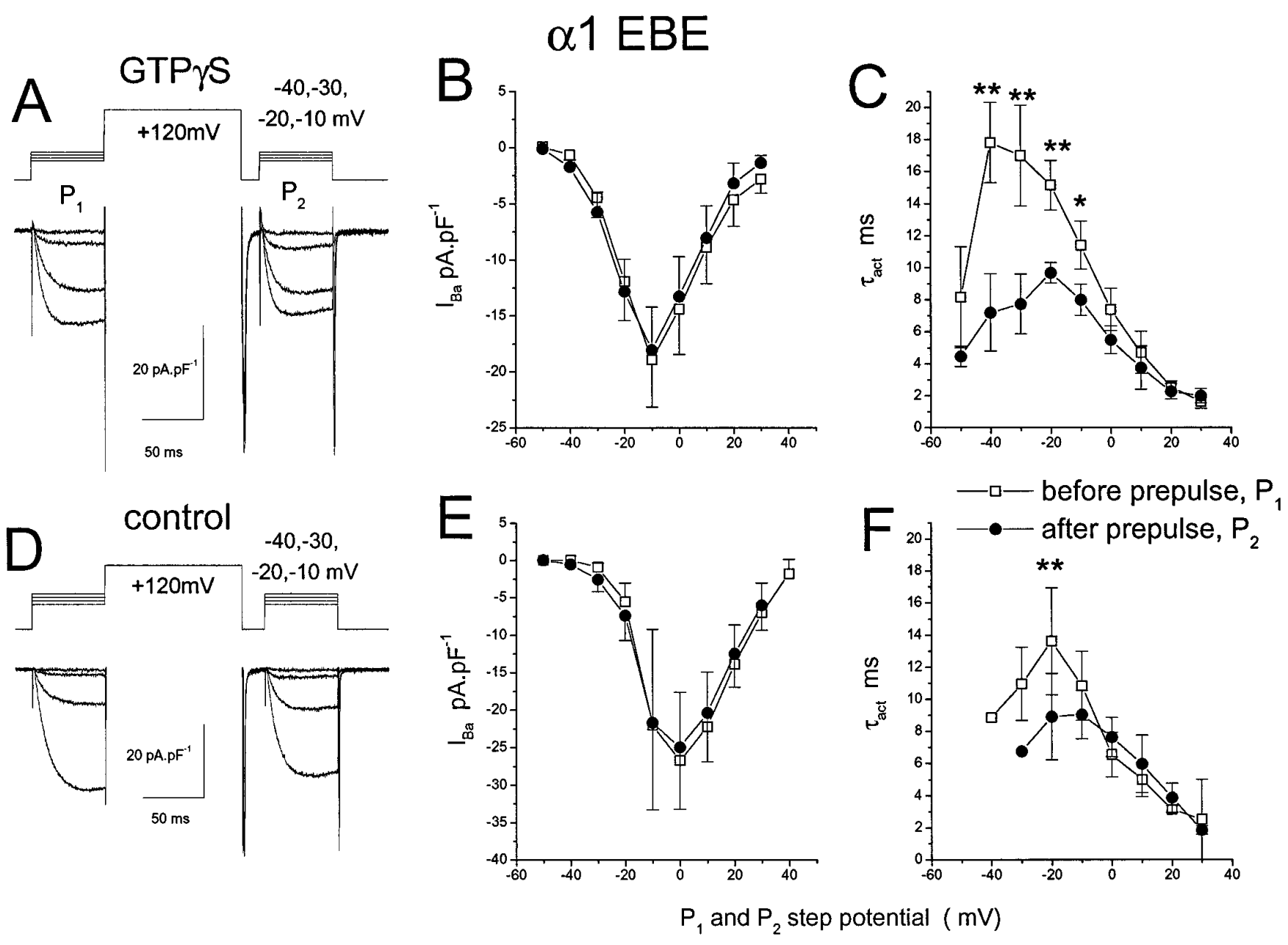

Figure 5. Cells were transfected with the $\alpha 1 \mathrm{EBE}$ chimera, together with $\alpha 2-\delta$ and $\beta 1 \mathrm{~b}$, and experiments were performed exactly as described in the legend to Figure 4 . The mean \pm SEM is given for nine GTP $\gamma$ S-modulated and five control cells. The statistical significance of difference between both $\tau_{\mathrm{act}}$ and $I_{\mathrm{Ba}}$ amplitude evoked in $P_{1}(\square)$, and $P_{2}(\bullet)$ was determined by paired $t$ test; ${ }^{*} p<0.01,{ }^{* *} p<0.001$.

\section{Role of the cytoplasmic I-II loop of $\alpha 1 \mathrm{~A}$ and $\alpha 1 \mathrm{~B}$ in G-protein modulation}

The cytoplasmic I-II loop contains the major binding site for the calcium channel $\beta$-subunit (Pragnell et al., 1994; De Waard et al., 1995; Witcher et al., 1995), the association of which modifies the properties of calcium channel $\alpha 1$-subunits (Lory et al., 1993; Neely et al., 1993; Stea et al., 1993; Berrow et al., 1995). We have shown previously that the presence of the calcium channel $\beta$-subunit reduces the ability of native neuronal calcium channels to be modulated by G-protein activation, because depletion of calcium channel $\beta$-subunits from dorsal root ganglion neurons by antisense oligonucleotide injection enhanced the ability of the calcium current to be modulated by $\mathrm{GABA}_{\mathrm{B}}$ receptor activation (Campbell et al., 1995b). This result was confirmed in an oocyte expression study (Bourinet et al., 1996) in which the coexpression of a calcium channel $\beta$-subunit with $\alpha 1 \mathrm{~A}$ decreased the modulation observed as a result of activation of expressed opiate receptors. We put forward the proposal that there is either direct or allosteric competition between the activated G-protein subunits and the calcium channel $\beta$-subunits for binding to the calcium channel $\alpha 1$-subunit (Campbell et al., 1995b). It is, therefore, feasible to speculate in the light of the present results that the I-II loop of the calcium channel $\alpha 1 \mathrm{~B}$ - and $\alpha 1 \mathrm{~A}$-subunits contains an essential site of interaction required for G-protein modulation.
Therefore, because our results indicate that the I-II loop of $\alpha 1 \mathrm{~B}$ and, to a lesser extent, $\alpha 1 \mathrm{~A}$ confer G-protein sensitivity on the $\alpha 1 \mathrm{E}$ calcium channel, it would seem likely that the G-protein subunits mediating this effect (Herlitze et al., 1996; Ikeda, 1996) bind to a region on the I-II loop of $\alpha 1 \mathrm{~B}$. We have preliminary evidence that $\mathrm{G} \beta \gamma$ mediates the observed effects associated with the I-II loop (G. J. Stephens, N. S. Berrow, A. C. Dolphin, unpublished observations).

\section{Kinetic slowing, but not steady-state inhibition, is conferred on $\alpha 1 \mathrm{E}$ by the I-II loop of $\alpha 1 B$ or $\alpha 1 \mathrm{~A}$}

Insertion of the I-II loop of $\alpha 1 \mathrm{~B}$ into $\alpha 1 \mathrm{E}$ conferred on the resultant chimeric calcium channel one key characteristic of G-protein modulation, that of slowed activation and reversal of this slowing by depolarizing prepulses. The I-II loop of $\alpha 1 \mathrm{~A}$ produced a similar, although less marked, effect. However, the other response observed in $\alpha 1 \mathrm{~B}$, inhibition of the steady-state current amplitude, was not present in $\alpha 1$ EBE or $\alpha 1$ EAE. Several groups previously have noted differences between these two properties: kinetic slowing and scaled or steady-state inhibition (Ciranna et al., 1993; Diversé-Pierluissi et al., 1995). It has been suggested that the kinetic slowing represents voltage-dependent inhibition, possibly a dissociation of activated G-protein from the channel at depolarized potentials (Boland and Bean, 1993). Oth- 


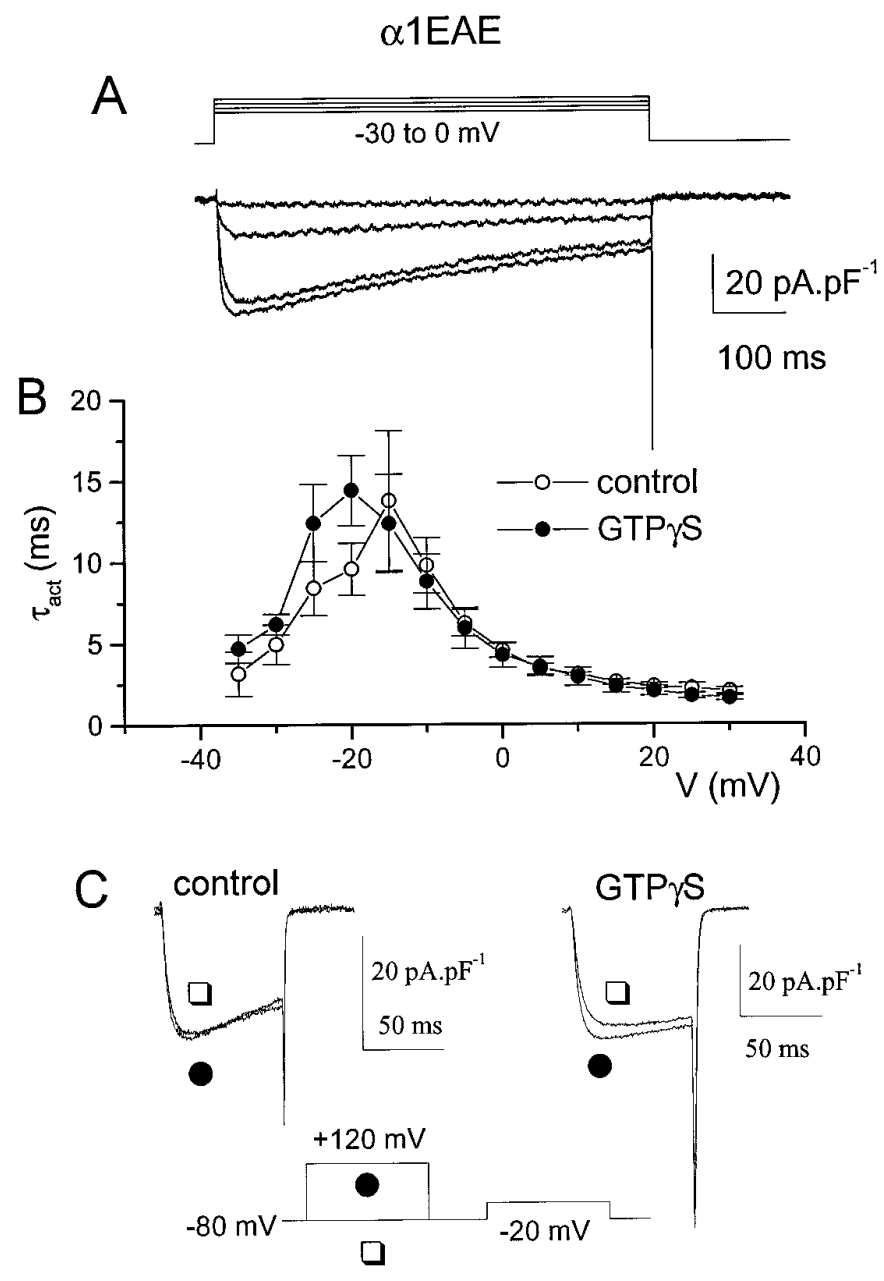

Figure 6. Cells were transfected with the $\alpha 1 \mathrm{EAE}$ chimera, together with $\alpha 2-\delta$ and $\beta 1 \mathrm{~b}$, and $I_{\mathrm{Ba}}$ was recorded after $3 \mathrm{~d}$ in culture. $A, I_{\mathrm{Ba}}$ was activated by $600 \mathrm{msec}$ steps to examine the rate of inactivation of $\alpha 1 \mathrm{EAE}$ $B, I_{\mathrm{Ba}}$ was activated by $100 \mathrm{msec}$ steps, and $\tau_{\text {act }}$ was measured as described in the legend to Figure 3 for cells recorded in the presence of $100 \mu \mathrm{M}$ $\mathrm{GTP} \gamma \mathrm{S}$ in the patch pipette $(\bullet, n=5)$, or in its absence $(\bigcirc, n=7) . C, I_{\mathrm{B}}$ was recorded in the presence $(\bullet)$ or absence $(\square)$ of a $+120 \mathrm{mV}$ depolarizing prepulse applied $30 \mathrm{msec}$ before the test pulse to $-20 \mathrm{mV}$ for a control cell (left) and a cell containing GTP $\gamma \mathrm{S}($ right). Prepulse facilitation was observed only in the GTP $\gamma \mathrm{S}$-containing cell.

ers have found the steady-state inhibition to be a voltageindependent process (Luebke and Dunlap, 1994), although in many instances prepulse facilitation of G-protein-modulated currents not only restores the control rate of activation of the current but also markedly increases its amplitude (Ikeda, 1991, 1996). A number of pieces of evidence have been put forward to suggest that the two processes involve different calcium channel subtypes (Ciranna et al., 1993), although this would seem unlikely here, because both effects are observed for cloned $\alpha 1 \mathrm{~B}$. However, it also has been suggested that they involve different mechanisms (Diversé-Pierluissi et al., 1995), kinetic slowing being a direct G-protein-mediated process and steady-state inhibition resulting from $\mathrm{G} \beta \gamma$ activation of the protein kinase $\mathrm{C}$ pathway. The present results would support the hypothesis of two separate mechanisms and would suggest further that whereas kinetic slowing involves the I-II loop of $\alpha 1 \mathrm{~B}$ and, to a lesser extent, $\alpha 1 \mathrm{~A}$, another region apart from this loop may be responsible for the G-proteinmediated steady-state inhibition of calcium channel current. How- ever, it is also clear that the kinetics of inactivation of the channel will affect the ability to observe prepulse potentiation of calcium currents, and we have shown in the present experiments that $\alpha 1 \mathrm{EBE}$ shows more rapid voltage-dependent inactivation than $\alpha 1 \mathrm{~B}$. In this context additional experiments are in progress to examine the properties of the mutant $\alpha 1 \mathrm{BEB}$, with the I-II loop of $\alpha 1 \mathrm{E}$ inserted into $\alpha 1 \mathrm{~B}$.

\section{Role of the cytoplasmic I-II loop and IS6 in determination of inactivation kinetics}

Different calcium channel $\alpha 1$-subunits show different intrinsic inactivation rates (Ellinor et al., 1993), $\alpha 1 \mathrm{E}$ being the most rapidly inactivating. Furthermore, the binding of different calcium channel $\beta$-subunits to the $\alpha 1$-subunit modifies inactivation in a subunit-specific manner (Ellinor et al., 1993; Olcese et al., 1994). $\beta 2 \mathrm{a}$, in contrast to the other $\beta$-subunits, produces a marked reduction in inactivation rate (Ellinor et al., 1993; Olcese et al., 1994). It has been found that the extreme $\mathrm{N}$ terminus of the $\beta$-subunit is responsible for determining its inactivation properties (Olcese et al., 1994), whereas the binding domain for the interaction with the I-II loop of the $\alpha 1$-subunit is in the center of the $\beta$-subunit sequence (De Waard et al., 1994). In a previous study on chimeras between the slowly inactivating $\alpha 1 \mathrm{~A}$ and the rapidly inactivating $\alpha 1 \mathrm{E}$ (doe-1), it was found that a region including IS6 and stretching 19 amino acids into the I-II loop was important for determining the inactivation properties of the $\alpha 1$-subunit (Zhang et al., 1994). A subsidiary result observed in the present study is that the I-II loop of $\alpha 1 \mathrm{~B}$, when inserted into $\alpha 1 \mathrm{E}$, produces a current phenotype with inactivation kinetics intermediate between $\alpha 1 \mathrm{~B}$ and $\alpha 1 \mathrm{E}$, again implicating this loop in determination of inactivation properties. Similar results also were found for the I-II loop of $\alpha 1 \mathrm{~A}$ inserted into $\alpha 1 \mathrm{E}$. The only alteration in transmembrane segment IS6 was V293 $\rightarrow$ M, as described in Materials and Methods. Thus, from the present and previous result (Zhang et al., 1994) it is likely that the inactivation properties of the channel are determined both by the $\beta$-subunit and intrinsically by sites in IS6 and on the I-II loop, probably lying $\mathrm{N}$ terminal to the $\beta$-subunit interaction domain.

\section{REFERENCES}

Berrow NS, Campbell V, Fitzgerald EG, Brickley K, Dolphin AC (1995) Antisense depletion of $\beta$-subunits modulates the biophysical and pharmacological properties of neuronal calcium channels. J Physiol (Lond) 482:481-491.

Berrow NS, Brice NL, Tedder I, Page K, Dolphin AC (1997) Properties of cloned rat $\alpha 1 \mathrm{~A}$ calcium channels transiently expressed in the COS-7 cell line. Eur J Neurosci, in press.

Boland LM, Bean BP (1993) Modulation of N-type calcium channels in bullfrog sympathetic neurons by luteinizing hormone-releasing hormone: kinetics and voltage dependence. J Neurosci 13:516-533.

Bourinet E, Soong TW, Stea A, Snutch TP (1996) Determinants of the G-protein-dependent opioid modulation of neuronal calcium channels. Proc Natl Acad Sci USA 93:1486-1491.

Boyer JL, Hepler JR, Harden TK (1989) Hormone and growth factor receptor-mediated regulation of phospholipase $\mathrm{C}$ activity. Trends Pharmacol 10:360-364.

Campbell V, Berrow N, Dolphin AC (1993) $\mathrm{GABA}_{\mathrm{B}}$ receptor modulation of $\mathrm{Ca}^{2+}$ currents in rat sensory neurones by the G-protein $\mathrm{G}_{\mathrm{o}}$ : antisense oligonucleotide studies. J Physiol (Lond) 470:1-11.

Campbell V, Berrow N, Brickley K, Page K, Wade R, Dolphin AC (1995a) Voltage-dependent calcium channel $\beta$-subunits in combination with alpha-1 subunits have a GTPase activating effect to promote hydrolysis of GTP by $\mathrm{G} \alpha_{\mathrm{o}}$ in rat frontal cortex. FEBS Lett 370:135-140.

Campbell V, Berrow NS, Fitzgerald EM, Brickley K, Dolphin AC (1995b) Inhibition of the interaction of G-protein $G_{o}$ with calcium channels by the calcium channel $\beta$-subunit in rat neurones. J Physiol (Lond) 485:365-372. 
Ciranna L, Mouginot D, Feltz P, Schlichter R (1993) Serotonin inhibits $\mathrm{Ca}^{2+}$ currents in porcine melanotrophs by activating $5-\mathrm{HT}_{1 \mathrm{C}}$ and 5- $\mathrm{HT}_{1 \mathrm{~A}}$ receptors. J Physiol (Lond) 463:17-38.

De Waard M, Pragnell M, Campbell KP (1994) $\mathrm{Ca}^{2+}$ channel regulation by a conserved $\beta$-subunit domain. Neuron 13:495-503.

De Waard M, Witcher DR, Pragnell M, Liu H, Campbell KP (1995) Properties of the $\alpha_{1}-\beta$ anchoring site in voltage-dependent $\mathrm{Ca}^{2+}$ channels. J Biol Chem 270:12056-12064.

Diversé-Pierluissi M, Goldsmith PK, Dunlap K (1995) Transmittermediated inhibition of N-type calcium channels in sensory neurons involves multiple GTP-binding proteins and subunits. Neuron 14:191-200.

Dolphin AC (1995) Voltage-dependent calcium channels and their modulation by neurotransmitters and G-proteins: G. L. Brown prize lecture. Exp Physiol 80:1-36.

Dubel SJ, Starr TVB, Hell J, Ahlijanian MK, Enyeart JJ, Catterall WA, Snutch TP (1992) Molecular cloning of the $\alpha-1$ subunit of an $\omega$-conotoxin-sensitive calcium channel. Proc Natl Acad Sci USA 89:5058-5062.

Ellinor PT, Zhang J-F, Randall AD, Zhou M, Schwarz TL, Tsien RW, Horne WA (1993) Functional expression of a rapidly inactivating neuronal calcium channel. Nature 363:455-458.

Fujita Y, Mynlieff M, Dirksen RT, Kim M-S, Niidome T, Nakai J, Friedrich T, Iwabe N, Miyata T, Furuichi T, Furutama D, Mikoshiba K, Mori Y, Beam KG (1993) Primary structure and functional expression of the $\omega$-conotoxin-sensitive $\mathrm{N}$-type calcium channel from rabbit brain. Neuron 10:585-598.

Grassi F, Lux HD (1989) Voltage-dependent GABA-induced modulation of calcium currents in chick sensory neurons. Neurosci Lett 105:113-119.

Herlitze S, Garcia DE, Mackie K, Hille B, Scheuer T, Catterall WA (1996) Modulation of $\mathrm{Ca}^{2+}$ channels by G-protein $\beta \gamma$-subunits. Nature 380:258-262.

Hille B (1992) G-protein-coupled mechanisms and nervous signaling. Neuron 9:187-195.

Ikeda SR (1991) Double-pulse calcium channel current facilitation in adult rat sympathetic neurones. J Physiol (Lond) 439:181-214.

Ikeda SR (1996) Voltage-dependent modulation of N-type calcium channels by G-protein $\beta \gamma$-subunits. Nature 380:255-258.

Kim H-L, Kim H, Lee P, King RG, Chin H (1992) Rat brain expresses an alternatively spliced form of the dihydropyridine-sensitive L-type calcium channel $\alpha 2$ subunit. Proc Natl Acad Sci USA 89:3251-3255.

Kleuss C, Hescheler J, Ewel C, Rosenthal W, Schultz G, Wittig B (1991) Assignment of G-protein subtypes to specific receptors inducing inhibition of calcium currents. Nature 353:43-48.

Lory P, Varadi G, Slish DF, Varadi M, Schwartz A (1993) Characterization of $\beta$-subunit modulation of a rabbit cardiac L-type $\mathrm{Ca}^{2+}$ channel $\alpha_{1}$ subunit as expressed in mouse L cells. FEBS Lett 315:167-172.

Luebke JI, Dunlap K (1994) Sensory neuron N-type calcium currents are inhibited by both voltage-dependent and -independent mechanisms. Pflügers Arch 428:499-507.

McFadzean I, Mullaney I, Brown DA, Milligan G (1989) Antibodies to the GTP binding protein, $G_{o}$, antagonize noradrenaline-induced calcium current inhibition in NG108-15 hybrid cells. Neuron 3:177-182.

Menon-Johansson AS, Berrow N, Dolphin AC (1993) $G_{o}$ transduces $\mathrm{GABA}_{\mathrm{B}}$-receptor modulation of $\mathrm{N}$-type calcium channels in cultured dorsal root ganglion neurons. Pflügers Arch 425:335-343.

Mintz IM, Bean BP (1993) GABA B $_{\text {B }}$ receptor inhibition of P-type $\mathrm{Ca}^{2+}$ channels in central neurons. Neuron 10:889-898.

Neely A, Wei X, Olcese R, Birnbaumer L, Stefani E (1993) Potentiation by the $\beta$-subunit of the ratio of the ionic current to the charge movement in the cardiac calcium channel. Science 262:575-578.

Olcese R, Qin N, Schneider T, Neely A, Wei X, Stefani E, Birnbaumer L
(1994) The amino terminus of a calcium channel $\beta$-subunit sets rates of channel inactivation independently of the subunit's effect on activation. Neuron 13:1433-1438.

Pragnell M, De Waard M, Mori Y, Tanabe T, Snutch TP, Campbell KP (1994) Calcium channel $\beta$-subunit binds to a conserved motif in the I-II cytoplasmic linker of the $\alpha_{1}$-subunit. Nature 368:67-70.

Sather WA, Tanabe T, Zhang J-F, Mori Y, Adams ME, Tsien RW (1993) Distinctive biophysical and pharmacological properties of class A (BI) calcium channel $\alpha_{1}$ subunits. Neuron 11:291-303.

Schneider T, Wei X, Olcese R, Costantin JL, Neely A, Palade P, PerezReyes E, Qin N, Zhou J, Crawford GD, Smith RG, Appel SH, Stefani E, Birnbaumer L (1994) Molecular analysis and functional expression of the human type E neuronal $\mathrm{Ca}^{2+}$ channel $\alpha 1$ subunit. Receptors Channels 2:255-270.

Snutch TP, Leonard JP, Gilbert MM, Lester HA, Davidson N (1990) Rat brain expresses a heterogeneous family of calcium channels. Proc Natl Acad Sci USA 87:3391-3395.

Soong TW, Stea A, Hodson CD, Dubel SJ, Vincent SR, Snutch TP (1993) Structure and functional expression of a member of the low voltageactivated calcium channel family. Science 260:1133-1136.

Starr TVB, Prystay W, Snutch TP (1991) Primary structure of a calcium channel that is highly expressed in the rat cerebellum. Proc Natl Acad Sci USA 88:5621-5625.

Stea A, Dubel SJ, Pragnell M, Leonard JP, Campbell KP, Snutch TP (1993) A $\beta$-subunit normalizes the electrophysiological properties of a cloned N-type $\mathrm{Ca}^{2+}$ channel $\alpha_{1}$-subunit. Neuropharmacology 32:1103-1116.

Stea A, Tomlinson WJ, Soong TW, Bourinet E, Dubel SJ, Vincent SR, Snutch TP (1994) Localization and functional properties of a rat brain $\alpha_{1 \mathrm{~A}}$ calcium channel reflect similarities to neuronal Q- and P-type channels. Proc Natl Acad Sci USA 91:10576-10580.

Stephens GJ, Page K, Burley JR, Berrow NS, Dolphin AC (1997) Functional expression of rat brain cloned $\alpha 1 \mathrm{E}$ calcium channels in COS-7 cells. Pflügers Arch 433:523-532.

Tanabe T, Takeshima H, Mikami A, Flockerzi V, Takahashi H, Kangawa K, Kojima M, Matsuo H, Hirose T, Numa S (1987) Primary structure of the receptor for calcium channel blockers from skeletal muscle. Nature 328:313-318.

Tomlinson WJ, Stea A, Bourinet E, Charnet P, Nargeot J, Snutch TP (1993) Functional properties of a neuronal class C L-type calcium channel. Neuropharmacology 32:1117-1126.

Toth PT, Shekter LR, Ma GH, Philipson LH, Miller RJ (1996) Selective G-protein regulation of neuronal calcium channels. J Neurosci 16:4617-4624.

Tsunoo A, Yoshii M, Narahashi T (1986) Block of calcium channels by enkephalin and somatostatin in neuroblastoma-glioma hybrid NG108-15 cells. Proc Natl Acad Sci USA 83:9832-9836.

Wang HY, Pisano MR, Friedman E (1992) Age-related alteration in G-protein function in rat cortex. Ann NY Acad Sci 663:426-428.

Witcher DR, De Waard M, Liu H, Pragnell M, Campbell KP (1995) Association of native $\mathrm{Ca}^{2+}$ channel $\beta$-subunits with the $\alpha_{1}$ subunit interaction domain. J Biol Chem 270:18088-18093.

Yassin M, Zong SQ, Tanabe T (1996) G-protein modulation of neuronal class $\mathrm{E}\left(\alpha_{1 \mathrm{E}}\right)$ calcium channel expressed in $\mathrm{GH}_{3}$ cells. Biochem Biophys Res Commun 220:453-458.

Zhang J-F, Randall AD, Ellinor PT, Horne WA, Sather WA, Tanabe T, Schwarz TL, Tsien RW (1993) Distinctive pharmacology and kinetics of cloned neuronal $\mathrm{Ca}^{2+}$ channels and their possible counterparts in mammalian CNS neurons. Neuropharmacology 32:1075-1088.

Zhang J-F, Ellinor PT, Aldrich RW, Tsien RW (1994) Molecular determinants of voltage-dependent inactivation in calcium channels. Nature 372:97-100. 